\title{
THE PROFILE OF THE LEVEL OF ENDOGENOUS NO IN MIGRAINE SUFFERERS
}

\author{
Arman Yurisaldi Saleh ${ }^{1}$, Hasan Machfoed ${ }^{2}$, Kuntoro $^{3}$ \\ ${ }^{1}$ Ministry of Health, Jakarta, ${ }^{2}$ Department of Neurology, Faculty of Medicine, Universitas Airlangga, \\ ${ }^{3}$ Faculty of Public Health, Universitas Airlangga, Surabaya
}

\begin{abstract}
ABSTRAK
Migrain merupakan masalah kesehatan yang memiliki dampak besar. Perubahan neurokimia di dura, yang meningkatkan jumlah oksida nitrit, berasal dari aktivasi NOS (diinduksi NOS) berlebih selama ictal. Beberapa peneliti menganggap NO sebagai penyebab utama dari intensitas nyeri di ictal. Diagnosis migrain dipandu oleh International Headache Society. Harapannya, pemeriksaan ini dapat digunakan sebagai diagnosis yang lebih objektif di masa depan. Metode penelitian ini adalah analitik deskriptif. Penelitian ini dilakukan untuk menemukan tingkat endogen yang dihembuskan NO pada 91 subjek, yang terdiri dari 30 orang normal, 31 interiktal, 30 ictal. Pengecualian telah dilakukan sebelumnya. Sebuah peralatan validasi dan pengukuran telah dilakukan sesuai dengan pedoman American Thoracic Association. Hasilnya adalah tingkat endogen yang menghembuskan NO pada kelompok normal (median = 5), kelompok interiktal (Median = 11), kelompok ictal (median =14). Koefisien korelasi antara VAS dan tingkat endogen yang menghembuskan NO adalah 0.815. Jadi, ada peningkatan endogen NO pada orang normal, interiktal migrain, dan ictal. Korelasi kuat antara intensitas nyeri (VAS) dan tingkat endogen dihembuskan NO selama ictal. (FMI 2016;52:290-295)
\end{abstract}

Kata kunci: migrain, endogen dihembuskan NO.

\begin{abstract}
Migraine is a health problem which had big impact. A neurochemistry change in the dura, that is the increase of the amount of nitrite oxide, originated from an excessive NOS (inducible NOS) activation during ictal. Some researchers assume NO as a main cause of the pain intensity in ictal. Migraine diagnosis is guided by the International Headache Society. Hopefully, this examination can be used as a more objective diagnosis in the future. Methode of this research is descriptive analytic. This study to find the level of endogenous exhaled NO on 91 subject, consisting of 30 normal people, 31 interictal, 30 ictal. An exclusion was done previously. A validation equipment and measurement had been done in accordance with American Thoracic Association guidance. The result is level of endogenous exhaled NO on the normal group (median=5), interictal group (median=11), ictal group (median=14). Coefficient correlation between VAS and level endogenous exhaled NO was 0,815. So, there is an increase of the NO endogen level in the normal people, migraine interictal, and ictal. Strong correlation between intensity of pain (VAS) and level endogenous exhaled NO during ictal. (FMI 2016;52:290-295)
\end{abstract}

Keywords: migraine, endogenous exhaled NO.

Correspondence: Arman Yurisaldi Saleh, Ministry of Health, Jakarta. Phone: 082164000439. e-mail: armanyurisaldi@gmail.com

\section{INTRODUCTION}

Migraine is a health problem occurring in the society which had quite a big impact on the sufferer. Every year, ten million people in the United States are suffering from migraine. Sixteen percent of the total population suffers from migraine. This happens mostly to women than men $(18 \%, 16 \%)$. In Surabaya, in 1984 , amongst the 6.448 new patients at the clinic, 180 people are migraine sufferer (Riyanto 1955). At the Cipto Mangunkusumo Hospital, Jakarta, from the 1.298 new patients that come from January to May 1988, 273 of them are migraine sufferer (Riyanto 1955). A population study in Bogor shows that $61 \%$ of headaches occur in the age group of $25-54,8.6 \%$ of this group suffers from migraine, with the detail of $81.6 \%$ is suffering from migraine without aura, $16.8 \%$ migraine with aura, $0.6 \%$ migraine with complication, $1.2 \%$ cluster headache (Perdossi 2006).

Migraine, defined as one of chronic hindrance, which has a big impact, usually unilateral, a headache followed by an aura as a symptom (Dowson 2003). Migraine sufferer experiences a neurochemistry change in the dura brain membrane, originated from an excessive NOS (inducible NOS) activation, that is the increase of the amount of nitrite oxide. Inducible NOS (iNOS) is an enzyme that is proven to increase during a acute migraine ictal. If inducted, this enzyme stays inside the blood for 4 hours, whereas nNOS and eNOS don't (Schueren et al 2009). Some researchers state that NO is the source of the headache. Other researcher disagreed with this statement. NO becomes the source of headache is the exogenous NO donor, such as GTN (Glyseryl 
Trinitrate) which broaden the diameter of blood vessel in a great way that it stimulates the sensorical nerve fiber of the blood vessel's wall (Ahern et al 2000, Goadsby et al 2002a) Nitrite Oxide endogen can cause a headache when the process of the disease resulting too much NO. Some researchers proved that NO endogen plays a role as antinosciception. But if too much, NO will have a role in hyperalgesia and allodynia (Ahern et al 2000) The development of migraine therapy will improve the quality of life, reduces pain and the attendance list of the workers (Marcelo et al 2006). Until now, the migraine diagnosis is based on the International Headache Society criteria and tends to be subjective. There is not yet an objective parameter, such as laboratory examination which can be used as a source of migraine diagnosis (Dowson 2003, Goadsby et al 2002b, Greco et al 2010). There is a tendency that the research is merely measuring the endogenous exhaled NO in relation with the acute migraine ictal (Schueren et al 2009). The measurement of the NOS level in the blood during an acute migraine ictal is not practical, because a laboratory examination using radioactive is needed (Ahern et al 2000, Cohen 1999) Measuring the nitrate level in the blood as an image of the NOS activation is proven to be incorrect because due to its unstability, whereas nitrate can be in the form of germ metabolism in the intestine (Vints et al 2005).

The measurement of the endogenous exhaled NO level on the migraine sufferer is not painful and easy to do. There are many types of the NO exhalation equipment, and they have also been validated and recommended by ATS (Alving et al 2006). Hopefully this examination can be used as a more objective migraine diagnosis in the future based on the diagnostic study (Alving et al 2006). The research which shows the endogenous exhaled NO level on the migraine sufferer has not yet been done in Indonesia. Until now, there is only one research which measures the endogenous exhaled NO level on the migraine sufferer using a NO exhalation equipment done by Van der Schueren and colleagues, who want to prove that there is an increase of endogenous exhaled NO level during a acute migraine ictal (Schueren et al 2009). This research found the mean of the endogenous exhaled NO during the migraine ictal, inter-ictal and on normal conditions. The measurement is done in 2-72 hours after a acute migraine ictal, but has not yet found any significant differences.

\section{MATERIALS AND METHODS}

This is a descriptive analytical research study, to find out the endogenous exhaled NO level in the migraine sufferer in-ictal, inter-ictal and on normal conditions.
An analysis whether there is a correlation between a clinical repair in the VAS scale towards the endogenous exhaled NO level is done on this research. This research is done at the clinic of the Pondok Bambu women and children prison, East Jakarta, from February 17th 2010 to July 31 st 2010 . The populations are all migraine patients who come to the clinic at the Cipinang Prison Hospital, Jakarta, Cipinang Prison clinic, The Pondok Bambu State Prison, Salemba, Tangerang, Bekasi and private practice. The sample populations are all patients who are migraine sufferer that fulfill the inclusion criteria, and they are migraine patients with aura and without aura, in accordance with the IHS (International Headache Society) criteria, with the age range of 19-55, with the education background of at least high school, male and female, and willing to participate in the research. On the anamnesis, physical check-up, neurologically was in normal. Exclusion is done if a migraine attack occurs $>10$ times a month or if using a prophyilactic, or too much physical activity in the last one hour. There is a history of liver chirrosis, pneumonia, asthma, bronchitis and/or rhinitis that has been proven with a skin prick test, and saline challenge test. Consuming medication containing NO donor, such as nifedipin, regularly. Following relaxation exercises, such as Yoga, Taichi, Qi-gong and the kind. Consuming supplement/medicine which contains arginine and/or nitrate in the last twenty hours, smoking, hypertension, in the ovulation condition, and using hormonal contraception. The research data is written in forms. After going through an editing and coding process, the research data is then recorded in a magnetic disc to undergo a cleaning process. The median of endogenous exhaled NO level on the migraine inter-ictal group and in the normal conditions is done by using a Kruskal Wallis test. The correlation between VAS and endogenous exhaled NO is tested using a Spearman or Pearson test.

\section{RESULT}

According to Table 1, there is a significant difference between three migraine groups. According to the table 2 , there is a strong correlation between VAS with the endogenous exhaled NO level.

Table 1. The comparison of the endogeneous exhaled NO level

\begin{tabular}{|c|c|c|c|}
\hline & $\mathrm{n}$ & Median & $\mathrm{p}$ level \\
\hline Migraine ictal & 30 & 14.0 & $<0,001 *$ \\
\hline Migraine not in-ictal & 31 & 11.0 & \\
\hline Normal & 30 & 5.0 & \\
\hline
\end{tabular}




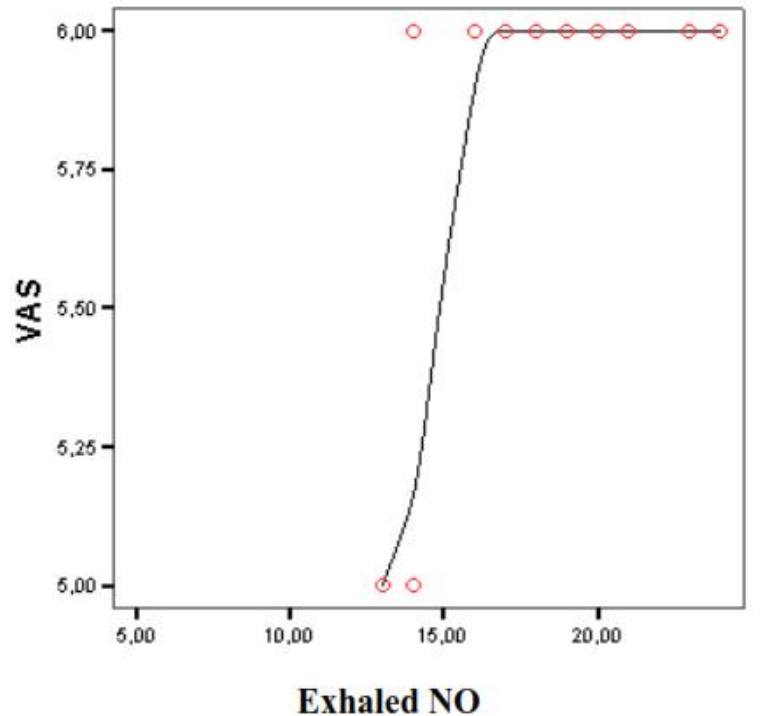

Fig. 1. The correlation between the pain degree of the migraine sufferer towards the endogenous exhaled NO level according to the VAS scale.

\section{DISCUSSION}

The research was held from February 17th 2010 until July 31st 2010 after receiving a permission from the Ethical Committee (February 16th 2010), which was also given by the Director General of the Law and Human Rights Department, to do a research on the inmates as the subject (October 20th 2009). The research was concentrated in the clinic of the Pondok Bambu women and children prison, located in East Jakarta. The subjects of the research are as follows: the migraine ictal group consisting of thirty people, migraine inter-ictal group consisting of thirty one people, and the normal group consisting of thirty people. The participants consist of 77 women and 14 men. This is suitable with the previous research which proves that the majority of migraine sufferer is women, because hormonally, the estrogen can influence the endotel cell of the respiration tract when releasing the NO to the respiration tract The validity selection in this research can be evaluated according to the valid selection criteria, that is the criteria of migraine diagnosis based on the International Headache Society (IHS) (Gupta et al 2007, Society 2005). The diagnosis guidance book can be found on the internet, on free sites which provide research materials. The explanation on the diagnosis criteria can be understood easily by medical staff. According to IHS, the e diagnosis criteria is the criteria that is most valid nowadays, so this research has a good selection validity.
The research staffs were medical staffs consisting of doctors and clinic paramedic of the state prison who do their duty during the working hours and outside of the working hours (the night shift at the clinic). The research staffs were able to diagnose migraine cases, tension type headache, and mixed migraine and tension type headache, after some training was given by the main researcher and some valid IHS guidance book were given. The recruitment of the research subject was done on the place where the research resources were available. The research subjects were analyzed, diagnosis was done and subjects were given medicine and free consultation by the staffs for twenty four hours. This research was not easy to be held at medical centres with the intensive care unit which only serve patients during working hours only, such as local government clinic that does not deal with treatment.

This research is done in the Care Unit Clinic Pondok Bambu Prison, East Jakarta, most of the research subject are prisoners of the prison with the capacity of 2000 people, consisting of children (below 19 years old) and women. The number of prisoners may change from time to time, in accordance with their law procedures. This condition cannot be achieved if the research is done in other health clinic.

The level of education of the prisoners varies, from primary school drop outs to university graduates. This research uses the minimum limit education level of high school to make the research procedure easier. The research subjects are also employees of the state prison and correctional facility, who are willing to participate in the research.

The measurement of the endogenous exhaled NO is done by using a calibrated Niox Mino equipment. Niox Mino is one of the Aerocrine products (Stockholm, Swedia) which was recommended and validated by the ATS (Society, 2005) This equipment also has a good reliability (Alving et al., 2006). The measurement method is explained to the subjects in detail, also using a recorded video (downloaded from the free sites on the internet) which shows the usage of the equipment. The room condition during the measurement has the same temperature and humidity by using an air conditioner for twenty four hours.

The measurement of the endogenous exhaled NO on the migraine sufferer in-ictal is done for not more than thirty minutes after the pain occurs. This is to reassure the relation between the time of the attack with the increase of the NO endogen exhalation. In Van der Schueren and colleagues' research (the previous research), the time of measurements are not the same. 
Measurement is done during the period of 2-72 hours since the pain occurs.

There was a pause during the research when facing a problem concerning the number of subject which was rather difficult to increase. The difficulty was due to one of the procedures that made the patients uncomfortable, which is the skin prick test. This test is one of the tests that the subject has to undergo, if she/he is willing to participate in the research. Although the number of subject is not as planned previously, the number of the subject in this research is still greater than the previous one. Standard deviation on this research is smaller than previous measurement, so that with the small number of subject, the effect size can be detected and statistically significant. This research also shows a significant difference statistically and clinically, concerning the level of endogenous exhaled NO between the migraine during ictal, not in-ictal and normal group.

The statistic analysis uses a comparison of more than two groups that do not comes in pairs; the migraine sufferer in-ictal group, migraine sufferer inter-ictal group, and normal group. The data distribution shows not normaly distribution, shown by skewness curve. Each data does not show any forms of normal frequency distribution. Statistically, this can become a proof that the similar thing will appear on a larger population. Adding the number of population will not change the skewness curve form into the normal distribution form (bellshape) (Dahlan 2010, Motulsky 2010). Only the kurtosis curve form will change into bellshape if the number of population is increased (Dahlan 2010, Motulsky 2010, Pett 1997, Sanders 1990). A transformation is done to know if the normal distribut-ion frequency in other mathematical form will be achieved by using software stata. The result of this data processing shows that the distribution frequency is still not normal, so that the data processing is in the form of non parametric. There is a strong correlation between VAS and the endogenous exhaled NO. This supports the hypothesis that NO is the pain mediator during the migraine attack (Marcelo et al 2006, Olesen \& Lance 2004, Sokolovic 2005).

This research proves the hypothesis that the endogenous exhaled NO is different for the normal group, migraine inter-ictal group and migraine ictal. Pathophysiologically, this can be explained based on the previous researches. The migraine sufferer, experiences a neurochemistry change inside the dural membrane, there is an increase of NO that comes from excessive iNOS (inducible NOS) activation. Inducible NOS is an enzyme that is proven to increase during a acute migraine ictal (Olesen \& Lance 2004, Schueren et al 2009, Sokolovic 2005). When inducted, this enzyme can last inside the blood for 4 hours, whereas eNOS and nNOS don't (Kurihara et al 1998). Some researchers state that NO is the cause of headache, while other researchers deny this opinion (Dowson 2003, Marcelo et al 2006, Olesen \& Lance 2004).

The NO that causes headache is the NO exogen donor, such as GTN (Glyseryl Trinitrate) which can widen the diameter of the blood vessel in a vast way, so that a stimulation on the sensoric nerve fiber located on the blood vessel's wall occurred Endogenous NO can also cause headache if the process produces too much NO, if the iNOS activation is too much, then the NO produced will also be too much (Cohen 1999, Garthwaite 2008a, 2008b).

This research found new numbers, comparing to the previous one. The average of migraine ictal is 16,13 ppb, migraine inter-ictal $11,23 \mathrm{ppb}$, and normal 6,67 $\mathrm{ppb}$ with a significant difference. Van der Schueren achieved the average number which shows that the NO exhalation during the migraine attack $12,5 \mathrm{ppb}$, comparing to the one before the attack is 9,9 ppb (Consort 2010, Dahlan 2010, Schueren et al 2009). This difference is probable due to the NO exhalation analyzer equipment used in this research is different (Consort 2010, Dahlan 2010, Schueren et al 2009); Van der Schueren and colleagues, did not explain whether the subject of the research fulfill the IHS criteria as pure migraine sufferer or mixed (mixed migraine and tension type headache). This research did not mention if the subject suffer from a mixed kind of headache (mixed migraine and tension type headache) (Consort 2010, Dahlan 2010, Schueren et al 2009); Van der Schueren and colleagues did not exclude the confusing factor completely before examining the endogenous exhaled NO level (Consort 2010, Dahlan 2010); and Van der Schueren and colleagues did not mention the time of measurement of the endogenous exhaled NO level clearly, starting from the time when the pain of migraine first appear. In this research, the measurement was done not more than 30 minutes from the time the patient first felt the pain (Schueren et al 2009b).

This research is very important, because endogenous exhaled NO was considered to have an important role in the pathopysiology migraine. This is the second research after the one done by Van der Schueren and colleagues. The endogenous exhaled NO level is hoped to be able to become an addition criteria to make the migraine diagnosis more objective, comparing to the one only based on IHS clinical criteria. The basis of this research is in accordance with Van der Schueren's, and can provide valuable input for researches in relation to the role of endogenous exhaled $\mathrm{NO}$ in the migraine 
pathophysiology and even researches relating to other diseases (Olesen \& Lance 2004).

The endogenous exhaled NO equipment, Niox Mino analyzer, is a new equipment in Indonesia. This equipment has a high reliability towards the NO analyz-er from the previous generation. Although very modern, the subjects still need to practice it by watching the demonstration on recorded video. If failure during the measurement occurs due to the inability of the subject to use the equipment, so that the research must be done from the beginning again, this resulted an increase in cost. The application of endogenous exhaled NO level measurement can be done in clinic in Indonesia, but first of all, equipment socialization must be done.

This kind of research is difficult to be done at health centers, due to the inability to provide such modern equipment, because the price of the equipment is too expensive. But it is hoped that this equipment can be used massively for the benefit of the people. Comparing to the equipment used in Van der Schueren's research, the Niox Mino has advantages in its small size and light weight (Alving et al 2006, Grob et al 2008, Hemmingsson et al 2004). This equipment can produce endogenous exhaled NO automatically so that it can achieve high validity and reliability (Alving et al 2006, Hemmingsson et al 2004, Society 2005). This equipment can also be accepted socially, culturally and religiously.

\section{REFERENCES}

Ahern G, Hsu S, Klyachko V \& Jackson M, 2000. Induction of Persistent Sodium Current by Exogenous And Endogenous Nitric Oxide. Journal of Biology Chemistry, vol. 275, no. 37, pp: 28810-28815.

Alving K, Janson C \& Nordvall L, 2006. Performance of a New hand-Held Device For Exhaled Nitric Oxide Measurement in Adults and Children, Journal of Respiratory Research, vol.7 no. 67.

Cohen R, 1999. The Potential Clinical Impact of 20 Years of Nitric Oxide Research. American Journal of Physiology of Heart and Circulatoty Physiology, vol. 276, pp: 1404-1407.

Consort, 2010. Consort: Transparent Reporting of Trials Retrieved from http://www.consort-statement.org/ consort-statement/13-19---results/item15_baselinedata/

Dahlan MS, 2010. Membaca dan Menelaah Jurnal Uji Klinis: Salemba Medika.

Dowson AJ, 2003. Migraine and other Headaches, Your Question Answered, London, Churchill Livingstone.
Garthwaite J, 2008a. Concepts of Neural Nitric OxideMediated Transmission, European JJournal of Neuroscience, vol. 27, pp: 2783-2802.

Garthwaite J, 2008b. Review Article : Concepts of Neural Nitric Oxide-Mediated Transmission, European Journal of Neuroscience, vol. 27, pp: 27832802.

Goadsby P, Lipton F \& Ferari L, 2002a. MigraineCurrent Understanding and Treatment,NEJM, vol. 346 no. 4, pp: 142-145.

Goadsby P, Lipton F \& Ferari L, 2002b. MigraineCurrent Understanding and Treatment,.NEJM, vol. 346 no. 4.

Greco, R., Gasperi V, Maccarrone M. \& Tassorelli C, 2010. The Endocannabinoid System and Migraine, Experimental Neurology, vol;. 224, no. 85-91.

Grob N, Laskowski D \& Dweik R, 2008. A Technical Report on Exhaled Nitric Oxide

Measurement: Asthma Monitoring in Athletes, Journal of Breath and Respiratory, vol. 2, no. 1-10.

Gupta S, Mehrotra S, Villalón CM, Perusquía M., Pramod RS \& Maassen VA, 2007. Potential Role of Female Sex hormones in The Pathophysiology of Migraine, Pharmacology \& Therapeutics, vol: 113 no. 24, pp: 89.

Hemmingsson T, Linnarsson D \& Gambert R, 2004. Novel Hand-Held Device Exhaled Nitric OxideAnalysis In Research And Clinical Application, Journal of Clinical Monitoring and Computer, vol. 18, pp: 379-387.

Kurihara N, Alfie M \& Sigmon D, 1998. Role of nNOS in Blood Pressure Regulation in eNOS Null Mutant Mice, Hypertension, vol. 32, pp: 856-861.

Marcelo E, Bigal MD, Richard B \& Lipton MD, 2006. Modifiable Risk Factors for Migraine Progression, Headache, vol. 46, pp: 1334-1343.

Motulsky H. 2010. Intuitive Biostatistics: Oxford University Press.

Olesen J \& Lance JW, 2004. Chepalalgia. The International Classification of Headache Disorders, vol. 24, pp: 20-25.

Perdossi, 2006. Epidemiologi of Headache in Indonesia, Bogor, PERDOSSI.

Pett AM, 1997. Nonparametric Statistics For Health Care Research, Statistic for Small Samples and Unusual Distributions, London, SAGE Publication.

Riyanto B, 1995. Masalah Diagnosis Nyeri Kepala, Cermin Dunia Kedokteran, vol. 104, pp: 10-15.

Sanders, 1990. Statistics a Fresh Approach, Elsevier.

Schueren BJ, Lunnon MW \& Laurijssens BE, 2009. Does the Unfavorable Pharmacokinetic and Pharmacodynamic Profile of the iNOS inhibitor GW273629 Lead to Inefficacy in Acute Migraine, Journal of Clinical Pharmacology, vol. 49, no. 281, pp: 67.

Schueren, BJ, Lunnon MW, Laurijssens BE, Guilard F, Palmer J, Hecken AV \& Hoon JND,2009b. Does the 
Unfavorable Pharmacokinetic and Pharmacodynamic Profile of theiNOS Inhibitor GW273629 Lead to Inefficiency in Acute Migraine? Journal of Clinical Pharmacology, vol. 49 pp: 281-290.

Society AT, 2005. ATS/ERS Recommendations for Standardized Procedures for The Online and Offline Measurement of Exhaled Lower Respiratory Nitric Oxide and Nasal Nitric Oxide, American Journal of Respiratory of Critical Care Medicine, vol. 171, pp: 912-930.
Sokolovic E, 2005. Prevalence of Tension-Type Headache And Migraine Among The Employees Of The Swiss University Hospital, Their Impact On Disability, Headache Management And Economic Impact For The Employer, pp: 1-5.

Vints A, Oostveen E, Eeckhaut G, Smolders M \& Backer W, 2005. Time-Dependent Effect Of NitrateRich Meals on Exhaled Nitric Oxide in Healthy Subjects, Chest, vol. 128, no. 4. 